\title{
The Doctrine of Federalism in an Unitarian State: A Study of Local Autonomy in Indonesia and Devolution Power in United Kingdom
}

\author{
M. Rifqinizamy \\ Correspondence: M. Rifqinizamy, Ph.D in Law Program, Faculty of Law (Fakultas Hukum), Universitas \\ Brawijaya, Jalan M.T Haryono, No.169 Malang 65145, Jawa Timur, Indonesia.
}

Received: October 12, 2013 Accepted: October 24, 2013 Available online: October 31, 2013

doi:10.11114/ijsss.v2i1.264

URL: http://dx.doi.org/10.11114/ijsss.v2i1.264

\begin{abstract}
Federalism is often identified as a federal state. It also has similarity to a "federation" term. The Federalism is actually a thought or a doctrine in which respects diversity in a unity of a state. Therefore, the federal states put inherent differences in ethnics, cultures, social, economy, and politics by managing a decentralistic state. It is usually conducted by federal states since the constitutions put the states more autonomous than the local government. The research of juridical, theoretical, doctrinual, and comparative methods found the fact that the unitarian states, such as Indonesia and United Kingdom, are actually federal states. The doctrin of federalism has been conducted by the two unitarian states in the local autonomy policy as stated in Indonesia Constitution, UUD NRI 1945. In United Kingdom, the doctrine of federalism is conducted in devolution power.
\end{abstract}

Keywords: federalism, local autonomy, and devolution power

\section{Introduction}

According to the residual power theory in a state, the residual power in federal state lies on federal or central government and the bigger power lies on the states of the state. In the other hand, the residual power of an unitarian state lies in the states while the bigger power lies in central government as the original power (Finer, 1995).

Nowadays, the residual power theory is nor relevant to be an indicator of distinguishing the power division in an unitarian state and a federal state. In implementing the autonomy of an unitarian state, the residual power is given to the central government and almost all the power lies in the region. Meanwhile, a federal state gives the residual power to the states, and the central government has the original power (Asshiddiqie, 1999). The situation can be seen from the construction of the constitution in Indonesia and Malaysia. Indonesia is an unitarian state and it applies autonomy. Malaysia is a federal state yet the original power lies on the central government. The relation between central and local government is drawn in the three models of relationship as stated by Clarke and Stewart. First, the relative autonomy model which gives big freedom toward the local government respecting the existence of the central government. The emphasis of this model is on the freedom to act for the local government in running the duty and responsibility which had been ruled by the constitution.

Second, the agency model in which the local government does not have enough power so that it is ruled only as the central government's agent to implement its policy. Third, the interaction model which the existence and the form of the local government are determined by the interaction of central government (Batley et al., 1991).

Based on those three models, there are two groups of relationship in every form of state, including an unitarian state and a federal state. Firstly, the government is held by the central government without any decentralization. The whole government becomes the authority of the central government; whether it is in a form of an unitarian state, a federal state, or a confederation state (Rondinelli, 1990).

Secondly, although the governmental business can be held based on decentralization, it has never been exclusively becoming the authority of local autonomy. Those who cannot hold the subunitarian stateal government will also be the authority of central government while others will be decentralized, Maddick explained (Maddick, 1996).

According to Maddick's theory, decentralization does not always exist in an unitarian state. The federal state may also hold on centralization. Arend Lijphart in Daniel J. Elazar stated, "The fundamental distribution of 
powers from a single center or down a pyramid (Lijphard, 1999). Lijphart, who did a research within 36 states in 1945-1999 to an unitarian state and a federal state, found that the decentralization degree in the two different kinds of states is diverse (Ibid, p.188). In the research, Lijphart stated that the choices of federalism are done by the states which have two main characteristics; large population and plural societies. Lijphard (1999) stated:

Federalism tends to be used in two kinds of states: relatively large states and plural society. The large states in terms of population included in this study, India and the United States, are both federations....Four of nine federal systems are plural states: Belgium, Canada, India, and Switzerland...In the plural societies, federalism performs the special function of giving autonomy to ethnic authorities (Ibid, p. 195).

Based on the background, this research is conducted to find out whether federalism can be implemented in an unitarian state in which the characteristics of the power are dominant in central government instead of in region. Therefore, this research conducts two policies made by two Unitarian states; Indonesia and United Kingdom.

\section{Research Methodology}

\subsection{Research Design and Purposes}

The research design of this research is normative-law research (Soekanto, 50-51) which is also well known as doctrinal-law research. According to Wignyosobroto (2006), this research is a kind of research which is developed based on the developer's doctrine (Ibid). The purpose of this research is to solve a problem (Marzuki, 2005).

\subsection{Research Approaches}

Based on the research object, the approaches of the research are statute approach, historical approach, theoretical approach, and doctrinual approach (Marzuki, 2005).

\subsection{Kind and Source of Law Data}

Since this research is a dogmatic research, the sources of law data in this research are primary law, secondary law, and tertiary (Soekanto, 1979). These three law sources are the secondary data of the research (Soekanto et al., 2011).

The primary law of this research is the law that becomes the focus of the research. Secondary law of this research is the supporting law of the primary law. They are: 1). Court Note of $M P R / D P R / D P D, 2$ ). the experts' opinion in law, politics, Local autonomy, 3). Law literatures, 4). Dissertations, theses, and research report, and 5). Articles and magazines. This research also uses tertiary data which are law dictionary, language dictionary, and encyclopedia.

\section{Discussion}

\subsection{The Essence of Federalism}

Federalism is well known as a federal state as well (King, p. 135). Few people understand that the true federalism means a thought or a certain doctrin related tp the relationship between central and region. According to Preston King, a federal state is sometimes contrary to the sovereignty theory (Ibid). The sovereignty theory was introduced by Jean Bodin, Thomas Hobbes, Spinoza, and Austin (Marbun, 1982). The founders of sovereignty theory believed that it is something genuine, supreme, and undivided. At this point, the critism toward the doctrin of federalism appears.

Prodount, a French politic expert was the first perso who stated the federative principal (Paris, 1863). Theoretically, there are two terms related federalism; federalism and federation. Friderich defined federalism as a unity which respects diversity in it. He stated,"federalism as a union groups, united by one or more common objectives, but retaining their distinctive group character for other purposes (Frederich, 1964).

Federation is defined as a governmental form which consists of two or more union groups of governments to make a bigger government. It is implied in Freeman's view as stated by Burger (2006): "Federation was a mechanism of compromise between two opposing political forces under any of these three classes of government. It was an intermediate state that combined the advantages of the large state - peace, orderand general well-being - with those of the small state - the full development and authonomy of the individual citizen" (Burger, 2006).

During its development, those two views defined federalism into at least two points of view. The first one, federalism as an ideology and the second one, federalism as an institution. In the first point of view, federalism is defined as a doctrine that support the acceptance of diversity in an unitarian state for its unity. This first group 
sees the federative doctrin as something softer and ideologic, as A. Marc and Bernard Voyenee supported this point of view. They defined the federalism idea as a doctrin of diversity in a state (King, 1982).

The second group suggested federalism as the federal state itself. In this group's point of view, federalism is a strict distribution of power between central and local government, and it is formulated in a standard form as a federal state, which is state to an unitarian state that is usually emphasized in constitution.

The experts who support the second point of view are R. Aron, H. Brugmans, Duerlien. The second opinion is viewed as a point of view toward a federation or the existance of federal state itself as many people have believed these days (Ibid, p. 25). According to this group, federalism can never be exist without proceeding by the existance of the federal state first. In the other words, an unitarian state will never be exist without the presence of federalism.

However, the other group of ideologic federalism has different point of view. They believed that federalism is a doctrine that should not be held in a form of alliance state. The federalism doctrine which consider diversity may also be applied in an unitarian state. In this context, there arre three kinds of federalism according to its orientation: centralistic federalism, decentralistic federalism, and balanced federalism (Ibid).

For those who believed in ideologic federalism, it is referred as an ideology. It is something constructed as a doctrine. Alexander Marc in his book stated," federalism became a doctrine" in the $19^{\text {th }}$ century. P.J Prodount as the founder of federation theories stated, "truth is one". According to King, the truth means Prodount aims to make his idea about federalism became the only doctrine and it might be formulated in constitution in many states (Ibid, p. 20).

The idea of federalism of Prodount at that time was defined as the federalism values which respect the regions. Prodount as the founder of federalism theory did not mention that federalism should be done by creating a federal state. He stated, "the sole constitution which an astringent reason will compel the peoples of the world to adopt is federalism".

As the follower of Prodount's idea, Marc stated that federalism is an ideology which will lead to revolutionary arisen. Marc put the federalism as the constructive way out to unite all activities, problems, and many human desires. According to Marc, federalism can create those things since it is not the totality which makes human life is fully depended on it. (Alexander, 1961) This Marc's analogy can also means that a government territory should not be dully guarded by others, even though it has a higher degree hierarchically. Shortly, the differences between ideologic federalism and institutional federalism can be seen in Table 1

Tabel 1. The Differerences Between Institutional Federalism and Ideological Federalism

\begin{tabular}{|c|c|c|c|}
\hline No. & $\begin{array}{l}\text { Points of } \\
\text { differences }\end{array}$ & Institutional Federalism & Ideological Federalism \\
\hline 1. & Arrangement & Arranged in constitution & $\begin{array}{l}\text { Arrangement can be set in laws and } \\
\text { regulation which level is under } \\
\text { constitution, e.g law. }\end{array}$ \\
\hline 2. & $\begin{array}{l}\text { Periodic of } \\
\text { Arrangement }\end{array}$ & $\begin{array}{l}\text { The policy of central authority and } \\
\text { local authority are held in long term } \\
\text { period in consistence and continuity } \\
\text { ways }\end{array}$ & $\begin{array}{l}\text { Held in quite short term period, some } \\
\text { are sporadic. }\end{array}$ \\
\hline 3. & Implementation & Implemented in federal states only & $\begin{array}{l}\text { Implemented in federal and non federal } \\
\text { states; unitarian states and confederal. }\end{array}$ \\
\hline 4. & $\begin{array}{l}\text { Exsisting } \\
\text { Constitution }\end{array}$ & $\begin{array}{l}\text { States (province) have their own } \\
\text { constitution, besides the federal } \\
\text { constitution }\end{array}$ & $\begin{array}{l}\text { Regions do not have to have their own } \\
\text { constitution. In states unitarian state, } \\
\text { constitution is only one, which is in } \\
\text { central level. }\end{array}$ \\
\hline
\end{tabular}

Source: Sum of several data by writer

\subsection{Federalism and Local Autonomy in Indonesia}

The autonomy term was derived from Greek, autos (individual) and nomos (laws: order) which meant individual laws" (Huda, 2009). In constitutional law context, autonomy means making their own laws and regulations (zelfwetgeving), however in the development of doctrin, it does not only mean zelfwetgeving (making local 
regulations) but also zelfbestuur (self-governmental). In running self-governmental, CW.Van der pot believed that Local autonomy as eigen huishouding which means running its own household (Marzuki, 2006).

Local autonomy in zelfbestuur meaning is in the same line with the public administration's point of view. In public administration, the autonom region is called local self government which can be seen as the region that rules its self. It practically different from "region" which is the implementation of local government policy which is called local state government, meaning the local governmental only (Nugroho, 2000).

Doctrinually, local autonomy can be defined as right, authority, and obligations given to autonom region to rule and control its governmental things and its people based on the society's aspiration to improve efficiency and outcome effectivity in governmental to serve the society and the development is carried out in harmonic ways with laws and regulations (Electronic Ensiclopedia Wikipedia, 2012). In other hand, what it was meant by autonom region is the unity of the law society which has borders that authorize to arrange ang cintrol the governmental jobs and society's needs based on their own aspirations (Ibid).

In Indonesia, the autonomy matters were stated explicitly in Constitution of UUD NRI 1945. In UUD NRI 1945, Indonesia declared itself as an unitarian state (Vide chapter 1 verse (1) UUD NRI 1945), but in other hand every local diversity and specialty to develop, one of the way is through local autonomy (vide chapter 18 UUD NRI 1945).

Formatively, it is explicitly can be seen in the formulation process of chapter 18 UUD NRI years 1945 which stated as follows:

(1) The Republic of Indonesia is divided into provinces and each province is divided into regency and city, which each province, regency, and city has local governmental arranged by constitution.

(2) The governmental of province, regency, and city arrange theit own governmental matters based on autonomy and agency's delegation's principle.

(3) The governmental of province, regency, and city have the local representative council which members are chosen from general election

(4) Governor, regent, and mayor as the head of governmental of province, regency, and city are elected democratically.

(5) Local governmental runs authonomy absolutely, except the governmental matters related to constitutions. Those matters become the autority of central government.

(6) Local governmen has right in deciding the additional local laws and constitutions to run autonomy and agency's delegation.

(7) The structures and procedures of local governmental are arranged in constitutions.

Those formulations above emphasize that local exsistence in an unitarian state are not working as administrative geographic division only, but also followed by giving right to the region to administer and run its governmental through autonomy.

In chapter 1 verse (5) UU number 32 year 2004 concerning the local governmental explains the meaning of Local autonomy (UU Number 32 year 2004 about local governmental), which explains that:

"Local autonomy is right, authority, and obligation the autonom region to administer and run its governmental matters and society needs based on the laws and regulations".

The concrete form of Local autonomy in a naation is the exsistence of governmental posts between central government and local government as the commision of chapter 18 verse (5) UUD NRI year 1945. As the implementation of chapter 18 verse (5) UUD NRI year 1945 as it was stated, the distributions of governmental matters were arranged in chapter 10 verse (3) UU number 32 year 2004. In the regulation, it is emphasized that the central governmental matters include the following aspects:
a. foreign affairs politic;
b. defense;
c. security;
d. justition;
e. moneter and national fiscal; and
f. religion. 
Based on the the regulation in chapter 10 verse (3) UU number 32 year 2004 above, Local autonomy clearly gives a big authority to each region. Local autonomy in indonesia, through the principle of big authority caarried out the meaning that the region is gived authority to administer and control all aspects of govermental outside aspects which become the responsibility of governnment in constitutions.

Local autonomy is the reflection of Indonesia's will as it is said in constitution to run decentralization. Decentralization is commonly defined as legal action from central government to give authority to the lower level of coordinators and institutions in politic administrations and hierarchy territorial. That was the definition of decentralization as general, which was the part of authority distribution of distribution of power vertically.

Ashiddiqie (2010) defined decentralization on the principle and practicality can be seen from the decentralized autonomy's policy which was carried out by decentralized the authorities in centralgovernmental. During the process of decentralization, the authority of central government is relocated from central level to local level as it should be so that the power shift of governmental can be materialized all over Indonesia (Asshiddiqie, 2010).

In relations, Hoessein (2007) stated that the doctrin of the developed decentralization by positive law of Indonesia showed that the doctrin of governmental authorities delegation from/by cental excecutive to autonom region. For this matter, decentralization in Indonesia is limited on governmental authorities scope which becomes the excecutive's competence (Hoessein, 2007).

\subsection{Devolution of Power in United Kingdom and Federalism}

In United Kingdom, federalism ideology was started from 1997. From that time, United Kingdom governmental under the prime minister of Tony Blair uttered the authority devolution's policy (devolution of power). That policy changed the relation patterns between central government and local in United Kingdom which was a united unitarian state county. As it was stated by Cusick, devolution of power can be defined as "the delegation of central government powers to subordinate units, these powers being exercised with some degree of autonomy though with ultimate power remaining with central government".

Based on the definition, devolution of power can be classified in two important elements, which are:

1. There is delegation of power from central government to local government; and

2. The delegation of power is characterized by giving the autonomy to the local government (http://www.thecep.org.uk/wordpress/devolution-for-United Kingdom/ accessed on 28 August 2013).

Theoretically, there is difference between devolution of power and distribution of power in federal state. Distribution of power in federal state is characterized by distributing the power between central and local government which is arranged explicitly in constitution. However, devolution of power gives power to distribute the power between central government and local government through policies given by central government.

The history of devolution of power in United Kingdom was started from the conflict between central government of United Kingdom and some regions such as Scotland, Wales, and North Ireland. Those regions felt that they have their own characteristics which were different from most regions in United Kingdom. Those differences were the basic reason for them to separate their state from United Kingdom.

That long conflict made Prescout, a parliament member from Labor party released the ideas to give devolution of power to each region on general election in 1997. The issue was responded positively by some parties and finally put Prescout as the vice of prime minister at that era (http://findarticles.com/p/articles/mi_qn4156/is_20070527/ai_n19184167 accessed on 28 August 2013).

Started from that moment, the government of United Kingdom administered devolution of power and left the original unitarian state system behind. By some parties, devolution of power uttered quasy-federalism in that state. The forms of devolution of power in United Kingdom are now different in each region.

Taking an example in Scotland, the form of devolution of power in the province is in form of legislative by forming the Scotland parliament. Devolution of power is implemented by giving authority to some policies to unitarian stateal parliament, which are policy in foreign affair, economic stability, policy in financial, defense and unitarian stateal security common market policy, and some policies in labor laws and social security (Philip, 1998).

However, the Scotland parliament is handed power to make regulations in local level in the aspects of health, education, training, local governmental, shipping, social work, housing, economic growth, environmental, agriculture, fishery and forestry, sport, art, and some policies outside the central government of United Kingdom's authority. 
Besides Scotland, devolution of power is practically carried out in Wales, North Ireland, and London. In Wales, the form of executive devolution is characterized by the existence of the election of assembly of Wales - a kind of big number of executive's heads -. Assembly of Wales has 60 members and has authority to administer laws and regulations in Wales in the aspects of Welsh language, art and heritage, industry and training, economic development, social services, agriculture, environmental, education, planning, housing, health and road management. The 40 of assembly's members are selected through general election and the rest 20 are chosen directly (Hazell, 2000).

In North Ireland, devolution of power was started by triangle negotiation in 1997 among the government of United Kingdom, Ireland kingdom, and parties in North Ireland facilitated by ex-senator of US George Mitchell. The negotiation uttered the arrangement reached on April 1998 which is known as Belfast Arrangement. The treaty was proposed because North Ireland was claimed as part of the republic of Ireland, while United Kingdom also claimed that it was part of its territory.

Devolution of power in North Ireland uttered constitutional devolution, which was the self-made of constitution in North Ireland that involved the republic of Ireland in the process. Belfast arrangement also uttered the people's representative council which consisted of some parties in North Ireland (Dearlove, 2008).

Another practice of devolution of power in United Kingdom was in London. In this capital city of United Kingdom, the devolution is carried out through executive devolution which was shown in the mechanism of direct election for the assembly and mayor in London. In the regions, the function of mayor was to coordinate the policies of the region while the function of the people's representative council was as a place to discuss some local policies, the principle planning and strategy, economic development and high level of education, and shipping.

In United Kingdom regions, 70\% member of house of representative was selected from the representative of local government and the rest percentage was selected from society's representative in that region. In London, with the devolution of power, the entire members of house of representative were elected directly by London's citizen (http://www.ucl.ac.uk/consitution-unit accessed on 29 August 2013).

In the context of devolution of power's implementation, there is a basic difference between the term of legislative and executive devolution. Legislative devolution of power was meant as power by local government (province, region) to make laws and regulations of local area. In legislative devolution of power, the elected House of Representatives' member had power to make their own regulations in their region. While in executive devolution, the power of government was relatively weak, in which the power to make laws and regulations was still on the hand of Unitarian stateal Parliament of United Kingdom which popularly called as Westminster.

\section{Conclusion}

Federalism, especially the ideology of federalism was not seen form of the unitarian states. Indonesia with the Local autonomy which was arranged in the constitutions emphasized that idea. It happened also with United Kingdom which ran the devolution of power by distributing many governmental matters to regions. The federalism as its essence is hoped to be able to be part of diversity in an unitarian state to unite the unitarian state.

\section{References}

Asshiddiqie, J. (1999). Reformasi Hukum Nasional. Jakarta : Sekretariat Negara

Asshiddiqie, J. (2010). Konstitusi dan Konstitusinalisme di Indonesia. Jakarta: Sinar Grafika.

Batley, R., \& Stoker, G. (1991). Local Government in Europe.

Burger, M. (2006). Comparative Federalism: Theory and Practice. London : Routledge Taylor \& Francis Group.

Finer, S. E. et.al. (1995). Comparing Constitutions. Oxford: Clarendon Press.

Frederich, C. F. (1964). New Tendencies in Federal Theory and Practice. Geneva : Sixth World Congress of IPSA.

Hazell. (2000). The State and the Unitarian states: The First Year of Devolution in the United Kingdom. London: Imprint Academic.

Hoessein, B. (2007). Perspektif Jangka Panjang Desentralisasi dan Otonomi Daerah. Jakarta: Bappenas.

Huda, N. (2009). Hukum Pemerintahan Daerah. Bandung : Nusamedia.

King, P. (1982). Federalism and Federation. London : Croom Helm Press. 
Lijphard, A. (1999). Pattern of Democracy: Government Forms and Performance in Thirty-Six States. Yale: Yale University.

Maddick, H. (1996). Democracy, Decentralization and Development. London: Asia Publishing House Bombay.

Marbun, S. F. (1982). Dimensi-Dimensi Pemikiran Hukum Administrasi Negara. Yogyakarta: UII Press Publisher.

Marc, A. (1961). The Fundamentals Philosophy of Federalism. Paris : Le' Press.

Marzuki, M. Laica. (2006). Berjalan-jalan di Ranah Hukum; Book one, Second Edition Revision. Jakarta : Sekretariat Jenderal \& Kepaniteraan Mahkamah Konstitusi RI.

Marzuki, Peter. M. (2005). Penelitian Hukum. Jakarta: Kencana.

Nugroho, R. D. (2000). Otonomi Daerah: Desentralisasi Tanpa Revolusi; Kajian dan Kritik atas Kebijakan Desentralisasi di Indonesia. Jakarta: Elex Media Komputindo Kelompok Gramedia.

Philip, S. (1998). Scotland's Parliament: Devolution, the Media and Political Culture.. London: The ARENA Working Paper Series.

Rondinelli, D. A. (1990). Decentralization, Territorial Power and The State : A Critical Response in Development and Change. London: Newbury Park and New Delhi (Vol 1)

Soekanto, S., \& Mamudji, S. (1979). Peranan dan Penggunaan Perpustakaan di dalam Penelitian Hukum. Jakarta: Law Documentation Center of Universitas Indonesia.

Soekanto, S., \& Mamudji, S. (2011). Penelitian Hukum Normatif: Suatu Tinjauan Singkat. Jakarta: PT.Raja Grafindo Persada.

Soekanto, S. Pengantar Penelitian Hukum. Jakarta: Penerbit UI Press Publisher.

Wignjosebroto, S. (2006). Hukum Sebagai Objek Penelitian dan Keragaman-Keragaman Definisi Konseptualnya. Malang: LPPM Universitas Widyagama Malang.

\section{(cc) $\mathrm{BY}$}

This work is licensed under a Creative Commons Attribution 3.0 License. 